
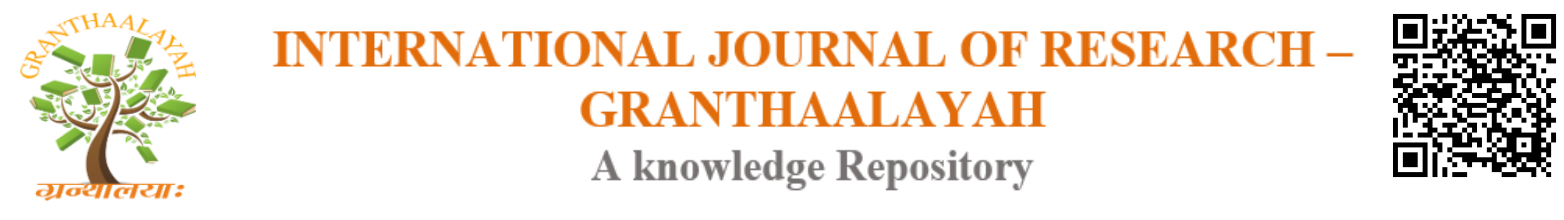

Social

\title{
FUNDAMENTAL POLITICO-LEGAL PRINCIPLES FOR SELF- DETERMINATION RIGHTS OF NATIONS AND NATIONALITIES
}

\author{
Nuriyeva Irada Tofiq ${ }^{* 1}$ \\ ${ }^{* 1}$ Ph.D Political Science, Professor of Department of "Social Sciences” of Azerbaijan State \\ University of Oil and Industry, Baku c
}

\begin{abstract}
The article "Fundamental politico-legal principles for self-determination rights of nations and nationalities" provides description of principles for self-determination rights of nations and nationalities during different epochs. The principles for self-determination rights of nations and nationalities was formulated during the Age of Enlightenment and French Revolution as a theoretical weapon against Feudal State laws and against the Tsar regime and serfdom in Russia during the first quarter of XIX century. The Democratic movements in Russia, USA and European countries were mostly interested in overthrowing monarchies rather than in rights of nations. Soviet government required class and dialectic approach serving to the interest of Bolsheviks.

When speaking about "rights of nations" or "rights of nationalities" W. Wilson intentionally forgot the "rights" of the native minor nations and nationalities and national minorities. So the issue of self-determination right for nations and nationalities remained unsettled.

In early XX century Azerbaijan Democratic Republic and now Azerbaijan Independent Republic provided the nations and nationalities living in the territory with the free space for development "regardless their sex, race, nationality, religious belief, social origin, political belief and other circumstances. In this case each nation, nationality and ethnic group must implement the level of their quality characteristics: steps and extent of development, number, occupied territory etc.
\end{abstract}

Keywords: Right for Self-Determination; Historical Approach; Quantitative Indicators.

Cite This Article: Nuriyeva Irada Tofiq. (2018). "FUNDAMENTAL POLITICO-LEGAL PRINCIPLES FOR SELF-DETERMINATION RIGHTS OF NATIONS AND NATIONALITIES." International Journal of Research - Granthaalayah, 6(2), 299-311. https://doi.org/10.5281/zenodo.1194740.

\section{Introduction}

The historical experience, both whole humanity and individual countries, proves that the oppression and inequality that whole nations have been subjected to throughout their history can be eliminated only through their free self-determination. This implies the realization of their right to self-determination, both through the formation of sovereign states, and the use of various 
forms of self-determination that presuppose the creation of autonomous entities within the territorial integrity of a state.

As we know, after the Second World War, there were tangible political changes on the world map. In order to prevent further redistribution of borders by military means the participants of the Potsdam Conference put forward the principle of territorial integrity of states as the fundamental principle of the world order. In 1945, the United Nations was created, which approved all the basic principles of international relations in its Charter.

It seemed that there came an era of relative calm in the world. However, the division of the world into two camps, socialism and capitalism, violated this tranquility, the time of the cold war between the two superpowers, the United States and the USSR, which adhered to the principle of territorial integrity in order to prevent new redistribution of the world came. In turn, the nations of the colonial countries fought for independence in the conditions of the collapse of the world colonial system. Such a contradiction arose from the fact that the principles of the territorial integrity of states and the right of nations to self-determination were not interpreted in interrelation and the forms and levels of implementation of the latter were not developed. Selfdetermination was understood only as the separation and creation of an independent state, while the principle of territorial integrity of states existed, which prevented a clear definition of the mechanism of action of these two principles.

\section{Materials and Methods}

The natural path of the development of the mankind led to the fact that the colonial countries also acquired independence, and soon they themselves faced the negative consequences of an arbitrary interpretation of these principles. This situation continues after the collapse of the USSR and Yugoslavia. Some national minorities in the newly independent states required the right to secession under the slogan of self-determination, contrary to generally accepted international practice. Such interpretation can lead to a redrawing of the territories of entire regions and interethnic conflicts, which we observe to this day.

There are many international organizations and agreements (the UN, the Council of Europe, the African Charter for Human and Nations' Rights, the European Charter for Regional and Minority Languages, the International Labor Organization, the League of Arab States, the Islamic Conference, etc.), whose immediate purpose is to stand on guard of democracy and international law. The UN, the Security Council and the European states adopted resolutions (for example, UN General Assembly Resolution 2625 (XXV) of October 24, 1970 and the Final Act on Security and Cooperation in Europe of August 1, 1975), where self-determination is not considered just as the formation of an independent state. As the forms of self-determination, an association or integration with an independent state or receiving any other political status, such as cultural autonomy, an autonomous region, an autonomous republic, without violating the principles of territorial integrity, and the inviolability of state borders, was named. Confirming the primacy of the interests of states, the UN indicated among the guidelines "territorial integrity and inviolability of the state border." This principle prohibits the seizure of foreign lands and the recognition of such acts. 
Thus, the problem of realizing the right of national minorities to self-determination without violating the territorial integrity of states, as well as international practice in this area requires a special wide political analysis.

Before analyzing the political bases, levels and methodological aspects of the "right to selfdetermination", it is necessary to consider the way of development of this principle, to reveal its fundamental moments and levels, the main historical conditions conducive to this development, and to investigate the causal relationship between the principles of "territorial integrity and inviolability of state borders" and "the right of a nation to self-determination". The issue of the rights of nations, ethnic and social groups has quite ancient historical roots. With the formation of the first slave states, there were wars and enslavement of certain nations. The Roman Empire was formed by conquering the entire Mediterranean Sea, the Greeks seized the coast and the islands of the Aegean Sea. Such enslavement led to the struggle of these people for their rights and certain laws were adopted that gave rights to the free population of these territories. However, the very term "the right of a nation to self-determination" originates from the liberation movements of the nations of Germany, France, and America in the XVII-XIX centuries, from the idea of the right of nations to determine their own destiny. This is reflected in the Declaration of Independence, prepared by Thomas Jefferson and adopted on July 4, 1776 in the Congress in Philadelphia. It was announced in the Declaration that the insurgent colonies were separated from England and united in a new independent state - the United States of America [1, p.9].

Declaration of the Rights of Man and Citizen adopted by the Constituent Assembly of France on August 26, 1789 can be considered as the same legal document.

It is known from the history of political doctrines that the principle of the nation's right to selfdetermination was formulated by bourgeois political thought in the process of developing theoretical weapons against the principles of feudal state law, in particular the principle proclaiming the monarch a carrier of sovereignty and the principle of "crown possession".

Despite the fact that the idea of the right of people to determine their destiny began to formulate in the XVII-XIX centuries in America, France, Germany, in which there was a small germ of the idea of a nation's right to self-determination, but the revolutionaries of the United States and Europe were more interested in overthrowing the monarchy, and not the rights of nations. "The English" fought for the independence of the North American colonies from Britain in their own interests, and not in the interests of the Indians. During the Great French Revolution, no one thought about the rights of the Basques, Corsicans, Avignans, Normans. In the XIX century in Russia, this process was hampered by the narrowness of the thinking of the Russian democrats. Great-power chauvinism, which so strongly entered their minds, did not allow these "humanists" to think that apart from Russians, other nations and nations on Earth also have the right to freedom.

Considering the ideas of the French enlighteners and revolutionary-democratic representatives of Russia, one can come to the conclusion that, first of all, they were interested in the issue of the elimination of feudal orders and absolute monarchy, for all this hampered the further development of society along the capitalist path. The issue of the right of nations to selfdetermination went into the background, and in such a multinational empire as Russia, it was 
desirable not to raise it at all. Similarly, this issue in Russia was not on the agenda after the February 1917 bourgeois-democratic revolution. As for the Bolsheviks, when considering this issue, the Soviet government put to the fore the idea of a class approach.

The principle of "the right of a nation to self-determination" was conceptualized after the First World War. In the 20th century, significant changes took place in the structural organization of the world community, and the accompanying regulatory legal criteria were noticeably refreshed. The course of political events, the widespread national liberation movements of the uprising at the beginning of the XX century prompted the mankind to reconsider many moral and ethical values, and forced politicians to recognize inalienable right for each people and nation to freely decide their own destiny.

At the same time, this right was often declarative: before the First World War, $70 \%$ of the world's population lived in colonial countries. US President Woodrow Wilson used the term "the right of a nation to self-determination" in his speech at the Paris Peace Conference, but this concept did not receive any legal context and was subsequently used in different meanings.

This principle, as a stimulating proletarian revolution, was included in the paragraph on the "right of a nation to self-determination" in the RSDRP program [2, pp. 289-294; 3, p.42]. Such attention to the national issue was quite natural for the opposition party in the multinational Russian Empire, in which the rights of a nation were not respected. They even refused to recognize the very existence of the Ukrainian and Belarusian nations in the Russian Empire. For this reason, Poles, Finns, Baltic people, the nations of the Caucasus and Central Asia dreamed of freedom from the empire. The Bolsheviks, sensing a weak element in the imperial mechanism, competently took advantage of this, uniting the enemies of the imperial regime with one slogan: "Every nation has the right to self-determination!". The Bolsheviks adhered to this slogan in practice during the first years of the struggle for power and at the beginning of the rule in Russia. For example, based on political expediency, the RSDP(b) headed by V.I. Lenin approved the unilateral separation of Norway from Sweden in 1905.

On November 2, 1917, the Soviet government promulgated the Declaration of the Rights of the Nations of Russia, which proclaimed the principles of the national policy of the new government:

1) Equality and sovereignty of the nations of Russia.

2) The rights of the nations of Russia to free self-determination, up to the separation and formation of an independent state.

3) Abolition of all and any national and national-religious privileges and restrictions.

4) Free development of national minorities and ethnic groups inhabiting the territory of Russia [4, p.40].

Following this declaration, the Council of People's Commissars adopted an Appeal to the Working Muslims of Russia and the East, in which, in particular it was noted: "From now on, your beliefs and customs, your national and cultural institutions are declared free and inviolable. Arrange your national life freely and without hindrance. You have the right to this " 1 .

${ }^{1}$ ibid., p.114 
After 1917, the Bolsheviks recognized the right of Finland, Ukraine, Poland, Belarus, and the Baltic republics to self-determination.

In 1918, after the collapse of the empire, the enslaved Caucasian nations declared independence. From the historical documents of the early XX century concerning the "rights of nationalities" in Azerbaijan, we learn that on May 28, 1918 the National Council of Azerbaijan declared in the Declaration of Independence: "... Henceforth Azerbaijan is a fully-fledged, independent state.

...The Azerbaijan Democratic Republic will provide wide scope for free development to all nationalities inhabiting its territory" [5].

Along with this, a number of articles of the leaders and members of the parliament of the republic were published in Azerbaijan Newspaper of May 28, 1919. In one of them, the 1st Deputy Chairman of the Parliament of the Azerbaijani Democratic Republic Hasan bay Aghayev set forth the policy of the state towards national minorities: "The attitude of Azerbaijan to national minorities is not prodigious. We think of all citizens of Azerbaijan as free and competent. We have no sons and stepsons. We only wish that Azerbaijani citizens, non-Turks are freed from alien influences and would be loyal to our independence. It's not just words. We have proved this by our entire policy towards national minorities"2

An interesting, in our opinion, "philosophical thought" about the freedom of the people and personality was expressed by Sheikh ul Islam of Azerbaijan Ahong Agha Aghazadeh in the article published in the same place: "To impede the free and independent existence of a person and a people is equivalent to the imprisonment of a bird by closing it in a cage, it thrashes and wants its liberation, it craves the freedom. The people, following the example of the same bird, conscious of their human rights, constantly and continually seeks freedom and independence and, eventually, reaches them or dies. Therefore, to condemn a person to failure in advance, as opposed to the natural course of life, is inconclusive and is the highest degree of despotism and opposition to the dictates of $\mathrm{God}^{3}$.

The leading party of Azerbaijan at the beginning of the XX century, the Turkic democratic party of the federalists Musavat was a supporter of federalism in the issue of "self-determination of nations" in its Program adopted on October 26, 1917 at the 1st Party Congress in Baku: "Only a federal decentralist system of a state can provide political rights of a nation in relation to a state and the spiritual and cultural rights in relation to religion. The federation is not a break with the center, on the contrary, it is a system that makes it possible to competently and appropriately distribute responsibilities, which will create an even greater connection with the center" [6, p.27]. Like every nation and its constituent nationalities, each religion and its persuasions, along with partial differences, nevertheless have something in common, and there are the same discrepancies and generalities among the individual groups of the population. That is why the natural way of all political, religious and national unity is the path of federation.

The Musavat Program details the party's vision of "state structure and autonomy". Below are a few points of this program relating to the topic:

\footnotetext{
2 “Azerbaijan”, 1919, May 28, No. 110.

${ }^{3}$ Ibid.
} 
...The people possessing a certain territory have the right to autonomy.

...People who do not have a particular territory have the right to national and cultural autonomy. ...All autonomous units communicate with the central government only in general matters, such as: the defense of a country, the monetary system, customs, foreign policy, the railway, mail and telegraphs, etc.

...The official language of each autonomous unit is the language spoken by the majority of the population in this area ${ }^{4}$.

The idea of "self-determination of a nation" was supported by socialists revolutionaries, members of the Parliament of the ADR. Point of view of the Socialists Revolutionaries Party was expressed by the Chairman of the Party Committee L.P. Umansky: "We reckon with the independence of Azerbaijan as a committed fact. Our party first put forward the issue of selfdetermination of nations in Russia, and it is understandable why our party welcomes the selfdetermination of a nation ${ }^{5}$.

Apparently, during the existence of the ADR (May 1918 - April 1920) "the right of selfdetermination of nations" in Azerbaijan was recognized unconditionally. However, the advocate of this right, the Azerbaijan Democratic Republic, fell from the aggression of another supporter, Soviet Russia.

So, from 1918 to 1920 , the nations of the Caucasus defended their independence, fighting with the troops of General Denikin, the enemy of the Bolsheviks.

The pragmatism and sober approach of the Bolsheviks to national self-determination can sometimes be envied. The Bolsheviks believed that the nations who experienced national oppression in tsarist Russia were potential allies of the revolution, and used the principle of the nation's right to self-determination as a powerful weapon in the legitimating of their power. A rare and little-known example was the holding of a referendum on the issue of national selfdetermination in certain areas of Povolzhye during the Civil War. For example, according to the agreement between the government of the RSFSR and the government of the Bashkir ASSR of March 23, 1919, a survey of the population of 6 volosts in Zlatoustovsky uyezd and 4 volosts in Ufa uyezd was carried out, which resulted in the determination of borders and national-territorial demarcation between the RSFSR and the Bashkir ASSR. Or, for example, on May 27, 1920, the Decree of the All-Russia Central Executive Committee and the Council of People's Commissars (CPC) established that until the citizens of Belebeevsky and Birsky uyezds freely expressed their will, the issue of their membership in the Tatar ASSR henceforth should remain open (by the way, under the results of conducted referendums, Birsky and Belebeevsky uyezds have not been included in Bashkiria). Such practical actions of the Bolsheviks in the field of the rights of nations quite deservedly raised the image of the new Russian government as democrats and humanists.

However, having consolidated their power, the Bolsheviks still keep the slogan "the right of a nation to self-determination" in practice, and having turning about 180 degrees, began to violate

\footnotetext{
${ }^{4}$ Guseynov M.D. - Turkish democratic party of federalists "Musavat" in past and present. Tbilisi: Zakkniqa, 1927, 1 Editions, 86 p., p.27

5 “Azerbaijan", 1919, May 28, No. 110.
} 
themselves this principle, as well as the principle of "territorial integrity and inviolability of borders." So, Soviet Russia once again conquered Ukraine and tried unsuccessfully to annex Poland in 1921. North Caucasian nations fighting for their independence in 1918-1920 with the army of Denikin, had to defend their freedom already from Soviet Russia.

On the afternoon of April 27, 1920, the units of the XI Red Army of the RSFSR crossed the Azerbaijani border, and committed aggression against the sovereign state with the aim of its occupation. Before the act of aggression as far back as in August 1919, G.V. Chicherin on behalf of the Soviet government assured the Azerbaijani people that "Soviet Russia does not intend at all to go on a campaign against Azerbaijan with weapons in hand to restore its power, and that it firmly stands on the principle of self-determination of nations" [7].

The clause about the "right of a nation to self-determination" in the program of the RSDLP was not specifically Bolshevik and even specifically Marxist, as communist ideologists persuaded. One cannot overlook the fact that the supporters of the national and cultural autonomy, with whom V.I. Lenin polemized during the adoption of the RSDLP program were also Marxists and sometimes even Bolsheviks. Just the Marxist doctrine demanded a consistent class approach to all social issues, including the national one. That's why as it's known V.I. Lenin after all spoke in favor of using the class and dialectical approach in the issue of the right of a nation to selfdetermination. Thus, the Bolsheviks support giving the right to self-determination up to secession, but not secession.

V.I. Lenin declared support for the self-determination of nations there and then, where and when it leads to the unification of working people, and was against such self-determination there and then, where and when it leads to their disengagement. This statement of V.I. Lenin answers the contradictory actions of the Bolsheviks in the national issue. As a pure pragmatist in politics, VI. Lenin used this problem not in the "interests of a nation", but in the interests of the Bolsheviks. His associate N.I. Bukharin went further in carrying out the class principle and wrote directly that one should not speak of "the right of a nation to self-determination" but of "the right of working classes". Under the "working class", Bukharin understood the "proletarian and semiproletarian masses" and asserted: "We are not talking about the right of a nation to selfdetermination, but about the right of the working classes of each nation to secession" [8, p.60].

But Stalin solved the "national issue" in his own way; when he needed to limit the right of a nation to self-determination, he gracefully summed up the "class base" under this restriction: "In addition to the right of nations to self-determination, I.V. Stalin said, there is still the right of the working class to strengthen its power, and the right to self-determination is subject to this right. There are times when the right to self-determination comes into conflict with another, higher right - the right of the working class that came to power to strengthen its power. In such cases, it should be said directly: "The right to self-determination cannot and should not serve as a barrier to the realization of the right of the working class to its dictatorship. The first must retreat before the second." [9, pp.126-127]

On June 29, 1919 in Versailles, the suburbs of Paris was signed a peace treaty, which concluded the First World War. In this war, England and France, with their allies, primarily the United States, defeated Germany, Austria-Hungary and their allies. The Versailles system radically changed the face of Europe. Germany was territorially curtailed, and Austria-Hungary was split 
into a number of states. At the time of the conclusion of the Treaty of Versailles, the Russian Empire had already collapsed. And then, with the formation of the Republic of Turkey the Ottoman Empire also relegated to oblivion. As a result, the number of states in Europe has almost doubled, 27 currencies appeared instead of 14, and the borders have increased by 12,000 miles.

At the Paris Peace Conference, when defining new frontiers in Europe, US President Woodrow Wilson proposed to implement the right of a nation to an independent state. Wilson defended his approach as a consistent democrat. But in addition to general ideas, he was guided also by pragmatic considerations, like V.I. Lenin.

By the time the Treaty of Versailles was signed, two opposing camps had already been formed in the world: bourgeois-capitalist and socialist-Bolshevik. And Wilson, naturally, as a true representative of his camp could not forget about the struggle of the two camps too. He considered it important to "intercept" the slogan of "self-determination" from the Bolsheviks, so that nations, becoming independent, remained bourgeois states. Then both he and Churchill believed that independent states would be a reliable "Sanitary Corridor" around Soviet Russia.

Wilson, brought up in the spirit of American democracy, repeated the mistakes of his predecessors in developing the "right of a nation to self-determination". He and his predecessors, speaking of "the right of the nations", or of "the right of a nation", deliberately forgot about the rights of "small indigenous nations and nationalities", "national minorities". Proceeding from this position, by the time of the signing of the peace treaties, the US could not solve their "national problems". "Indigenous people" of the United States, the Indians, as well as "national minorities", Negroes, immigrants from Africa had almost no rights in the United States.

"By deliberately" ignoring the "rights of nationalities", giving the right to self-determination to nations or large nations, Wilson at Versailles left the problem unsolved until the end, thereby creating new problems in national politics.

As a result of the Versailles-Washington system, it was not possible to create ethnically pure national states [10]. In every new nation-state there were many citizens of other nationalities, sometimes very significant in number. For example, in Poland almost one third of the population was made up of Ukrainians, Byelorussians, Germans, Lithuanians and 3 million Jews.

In Czechoslovakia, besides Czechs and Slovaks, there were also Sudeten Germans, Hungarians, Gypsies and Carpathian Ruthenians.

In Romania, there were the mass of Hungarians and Gypsies. In Hungary itself, only one-third of all Hungarians in Europe remained.

In Yugoslavia, Serbs, Croats, Slovenes, Bosnians, etc. were in one state.

In general, small multinational states appeared instead of large multinational empires. Nations and nations, whose names did not coincide with the names of states where they live, found their rights to self-determination restrained. 
When preparing the Treaty of the Versailles system, it became clear that it was difficult to determine a nation to which grant independence. As a result, some nations received it, and others were not provided with independence.

While all nations lived under the common scepter of one empire, they all seemed to be equal in their lack of rights. But when some of them suddenly became an independent nation with their own state, while others remained dependent, they had both offence and willingness to fight. And it turned out that after the emergence of almost a dozen new independent states, the number of nations in Europe struggling for independence increased ${ }^{6}$. The solution of the issue of the colonial territories of the collapsed empires after the First World War is also interesting. The leading countries of the United States, Britain and France showed particular interest to the colonies of Germany, and the Ottoman Empire at the Paris Peace Conference.

The League of Nations established at the Paris Peace Conference (1919), after the liberation of the nations of the colonies of these countries, immediately hastened to create a system of guardianship over these territories by distributing the mandates to Britain, France, Japan and Belgium. Thus, the nations of the former colonies of the Ottoman Empire and Germany became the property of the states holding the mandates instead of the right to self-determination.

After the Second World War, significant changes took place in the world. Despite the fact that the UN Charter (1945) recognized the principle of self-determination of a nation, the struggle around this principle did not stop. In particular, it developed in connection with the adoption of the Universal Declaration of Human Rights and the preparation of the Covenants on Human Rights. Then the representatives of the colonial powers managed to prevent the inclusion of an article on the right of nations to self-determination, proposed by the USSR in the text of the Declaration. Despite opposition from the colonial powers, the principle of self-determination was included in both draft Covenants on Human Rights, thanks to the efforts of states standing on anti-colonial positions [11, p.99].

The rejection of colonialism and the desire of the world community to end the injustices of the colonial system led to the adoption by the UN General Assembly of documents that developed the idea of self-determination. The struggle for independence and the development of democratic principles in international relations gave fruits.

The main and tangible step in the development of the principle of self-determination of nations was the adoption of the Declaration on the Granting of Independence to Colonial Countries and Nations in 1960.

It was an official recognition of the right for all nations and nations without exception to freely determine their future destiny. However, this did not mean anarchy in the realization of this right. The realization of the right of a nation to self-determination must not be accompanied by a violation of the same rights of other nations and nations.

${ }^{6}$ Gavriil Popov. The question of the right of Nations to self-determination (the Lessons of the Treaty of Versailles) // Moskovskiy Komsomolets, 2004, 09 Jul. 
The Declaration states that "the continued existence of colonialism hinders the development of international cooperation, delays the social, cultural and economic development of dependent nations and runs counter to the ideal of the United Nations."

The Declaration calls for "an immediate and unconditional end to colonialism in all its forms and manifestations" [12, pp.74-75], the measures to ensure the implementation of this provision are listed.

The Declaration on the Granting of Independence to Colonial Countries and Nations requires the cessation of any armed actions or repressive measures of any kind directed against nations struggling for their independence and enabling them to exercise their right to complete independence in conditions of peace and freedom. The states responsible for the administration of the non-self-governing territories undertake to take immediate steps to transfer all authority to the nations of those territories.

Recall that back in 1952, at the VIII Session of the UN General Assembly, Resolution 742/VIII/ was adopted, in which the list of the facts confirming the independence of one or another nonself-governing territory was officially given ie indicating the exercise by the people of the given territory of the right to self-determination in its full scope.

The Declaration 1960 also emphasizes that, by virtue of the right to self-determination, people establish their political status in accordance with freely expressed will and desire. The provisions of this Declaration were based on the resolutions of the UN General Assembly 2105/XX/, 2189/XXI/, 2326/XXII/, 2465/XXIII/ and others. The provisions of the Declaration recognize the legitimacy of the struggle waged by nations under colonial domination for the exercise of their right to self-determination and independence ${ }^{7}$.

The next steps in the development of the right of "a nation to self-determination" did not take a long time. Just two years later, the General Assembly adopted a resolution entitled Inalienable Sovereignty over Natural Resources (1962).

1966 was a rich of adoption a number of international instruments relating to human rights and nations: the International Convention on the Elimination of All Forms of Racial Discrimination [13, pp. 280-282]; The International Covenant on Civil and Political Rights and its Optional Protocol; International Covenant on Economic, Social and Cultural Rights [14].

\section{Results and Discussions}

The big capitalist powers, having lost the support of the colonial nations in the ideological war against socialism, began to hastily correct the mistakes made on the national issue after the Second World War. This was required by historical and political reality. However, the Soviet system, speaking with slogans about the rights of nations and nations, in reality was not consistent in the national issue.

\footnotetext{
${ }^{7}$ United Nations. Resolution adopted by the General Assembly at the XV session. New York, 1961, Vol. 1. pp.74-75 // Abroad, №35, $1999,23$.
} 
After the end of Second World War, certain countries of Eastern Europe (except Austria) liberated by Soviet troops from fascism unanimously "voluntarily", "without coercion from without", using the right to self-determination, declared themselves socialist or people's, or democratic states (but necessarily with Socialist orientation!). Even half the population of Germany, which recently fought against the USSR, as if waking from hibernation, realized that it turned out that the Germans in the soul were Communists (the GDR, Czechoslovak Soviet Socialist Republic, Poland People's Republic, etc.)

The XX century, especially its second half, was remembered by the development of democratic principles and their strengthening in most parts of the world. In 1956, a national uprising was violently suppressed by Soviet tanks in Hungary, in 1968 in Czechoslovakia, in April 1989 in Georgia, in January 1990 in Azerbaijan, in January 1991 in Lithuania, which were accompanied by great loss of lives and ended with the independence of the former countries of the socialist camp and the Union Republics.

Self-determination, as a system of definitions by people of their status, is only the beginning of a complex, long process, the outcome of which must be the achievement of the desired level of development. For this, it is necessary to ensure that all nations and nations have the right to selfdetermination and the freedom to exercise this right. However, the right to self-determination cannot be absolute. In order to avoid the growth of absolute freedom into the antipode of freedom, restrictors of freedom of self-determination are brought into arbitrariness and international law: "Any attempt aimed at partial or complete destroying the national unity and territorial integrity of a country is incompatible with the purposes and principles of the UN Charter" (Clause 6) [15]. Every step taken to realize the right to self-determination must be justified and conform to international norms.

In modern conditions, such forms of realization by nations, nations and national minorities of the right to self-determination are more acceptable for the international community, which have neither legal nor factual negative consequences for the territorial integrity of states, but are carried out within the framework of their sovereign rights. The principle of self-determination of nations and national minorities and the doctrine of the sovereignty of states supplement each other, for this reason the first principle cannot be considered in isolation from the second. The right of a nation to self-determination is its legitimate right. At the same time, each nation, people and ethnic group use the levels of self-determination, national-state, national-territorial, territorial and cultural autonomy, which, accordingly, depend on the population size, its territorial affiliation, the size of the occupied territory, the compact residence of nationalities in a certain territory, the level of development of the state of a subject and the specific political situation.

Each nation, each people, taking into account the above indicators, has the right to think about its self-determination. Naturally, the creation of a unitary, confederative or federal state can be the highest step for them. However, we must not forget that the creation of a state in a certain territory is an inalienable right of its original inhabitants - the dominant indigenous nations. The granting of such right only to dominant indigenous nations cannot be characterized as infringement of the rights of other nations and national minorities that inhabit this territory. 


\section{Conclusions and Recommendations}

Self-determination can be achieved also without the creation of new sovereign states. As the factors noted above are of no small importance in the choice of form and level of selfdetermination. Everyone is well aware that the goal of statehood is to provide the people living in its controlled territory with high political, economic, scientific, cultural, etc. development. Naturally, the nations without the necessary potential are unable to create such a state. In this sense, the federal state is the most suitable form of statehood for a multinational country. Therefore, self-determination in the federal state is the most optimal level for such nations.

In international practice, there is another level of self-determination: national-cultural autonomy, which contributes to the preservation of an original way of life, languages, cultures, traditions, etc. by representatives of different ethnic communities, in particular, by small nations, national and other minorities in the framework of the supremacy of territorial integrity and the sovereign rights of the states in whose territories they live.

Human rights are protected by the constitutions of many countries, as well as by international organizations. In the world community, the jurisdiction of each subject operates within the established boundaries, promotes the preservation of stability and international order, protects the national interests of all citizens and, if necessary, protects them from the destructive impact of external forces.

The Republic of Azerbaijan has always stated that the protection of the rights and freedoms of citizens is seen as the determining factor for the existence of a democratic society. According to Art. 19 of the Constitutional Act on State Independence of the Republic of Azerbaijan, all citizens of the Republic of Azerbaijan are equal before the law. The Republic of Azerbaijan, joining the Universal Declaration of Human Rights, the Final Act of the Helsinki Conference and other universally recognized international legal instruments, ensures the observance and unhindered implementation of all the rights and freedoms envisaged by them, irrespective of gender, race and nationality, religion, social origin, political opinions and other circumstances $[16$, pp.40, 45].

\section{References}

[1] American educators. Selected works in two volumes. Vol. 2. M.: 1969, 448 p., p.9

[2] Lenin the right of Nations to self-determination / complete works. 5th edition vol. 25. M: Gospolitizdat, 1961, 646 p., pp.289-294

[3] Lenin V. I. the discussion of self-determination / complete works. 5th edition vol. 30. M: Gospolitizdat, 1962, 561 p., p.42

[4] Decrees of the Soviet government. M: Gospolitizdat, 1957, vol. 1, 626 p., p.40

[5] “Azerbaijan", 1919, May 28, No. 110.

[6] Guseynov M.D. - Turkish democratic party of federalists "Musavat" in past and present. Tbilisi: Zakkniqa, 1927, 1 Editions, 86 p., p.27

[7] "Poverty", 1919, October.

[8] Bukharin, N.I. The program of the Communists (Bolsheviks). M., 1918, 60 p.

[9] Stalin I. V. Marxism and the national - colonial question. M.: 1938, 232 p., pp.126-127

[10] Gavriil Popov. The question of the right of Nations to self-determination (the Lessons of the Treaty of Versailles) // Moskovskiy Komsomolets, 2004, 09 Jul. 
[11] Current problems of international law (the conference Materials). April 9, 2003, 99 p.

[12] United Nations. Resolution adopted by the General Assembly at the XV session. New York, 1961, Vol. 1. Pp.74-75 // Abroad, №35, 1999, 23.

[13] The USSR and international cooperation in the field of human rightsю Documents and materials. M., 1989, 708 p., pp. 280-282

[14] The international covenants on human rights // the Collection of documents. Sanktpeterburg, 1993, $310 \mathrm{p}$.

[15] The UN Charter and the Status of the International Court of justice 1940. New York, 1946, 96 p.

[16] Commissioner for Human rights (Ombudsman) of Azerbaijan Republic, Professor Elmira Suleymanova, the general editorship. "The international conventions in the legislation with participation of Azerbaijan Republic". Baku: Law, 2003, 58 p., pp.40, 45

*Corresponding author.

E-mail address: iradanuri@gmail.com 